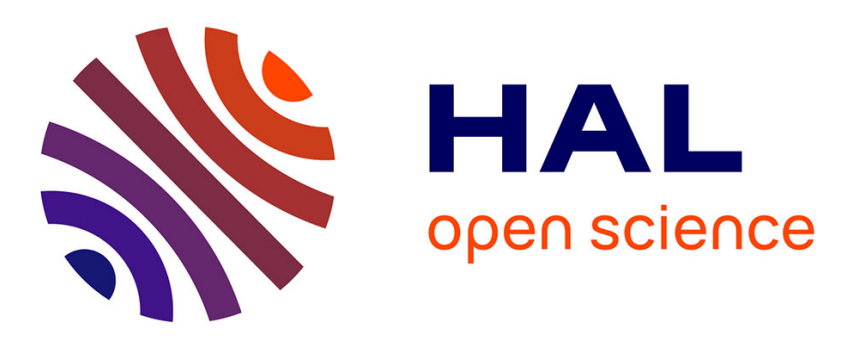

\title{
Differential modulation of the cytokine-induced MMP-9/TIMP-1 protease-antiprotease system by the mTOR inhibitor rapamycin
}

Bashier Osman, El-Sayed Akool, Anke Doller, Roswitha Müller, Josef

Pfeilschifter, Wolfgang Eberhardt

\section{To cite this version:}

Bashier Osman, El-Sayed Akool, Anke Doller, Roswitha Müller, Josef Pfeilschifter, et al.. Differential modulation of the cytokine-induced MMP-9/TIMP-1 protease-antiprotease system by the mTOR inhibitor rapamycin. Biochemical Pharmacology, 2010, 81 (1), pp.134. 10.1016/j.bcp.2010.09.011 . hal-00642428

\section{HAL Id: hal-00642428 \\ https://hal.science/hal-00642428}

Submitted on 18 Nov 2011

HAL is a multi-disciplinary open access archive for the deposit and dissemination of scientific research documents, whether they are published or not. The documents may come from teaching and research institutions in France or abroad, or from public or private research centers.
L'archive ouverte pluridisciplinaire HAL, est destinée au dépôt et à la diffusion de documents scientifiques de niveau recherche, publiés ou non, émanant des établissements d'enseignement et de recherche français ou étrangers, des laboratoires publics ou privés. 


\section{Accepted Manuscript}

Title: Differential modulation of the cytokine-induced MMP-9/TIMP-1 protease-antiprotease system by the mTOR inhibitor rapamycin

Authors: Bashier Osman, El-Sayed Akool, Anke Doller, Roswitha Müller, Josef Pfeilschifter, Wolfgang Eberhardt



PII: S0006-2952(10)00694-5

DOI:

Reference: doi:10.1016/j.bcp.2010.09.011

To appear in: $\quad B C P$

Received date: $\quad 16-6-2010$

Revised date: $\quad$ 9-9-2010

Accepted date: $\quad 10-9-2010$

Please cite this article as: Osman B, Akool E-S, Doller A, Müller R, Pfeilschifter J, Eberhardt W, Differential modulation of the cytokine-induced MMP-9/TIMP1 protease-antiprotease system by the mTOR inhibitor rapamycin, Biochemical Pharmacology (2010), doi:10.1016/j.bcp.2010.09.011

This is a PDF file of an unedited manuscript that has been accepted for publication. As a service to our customers we are providing this early version of the manuscript. The manuscript will undergo copyediting, typesetting, and review of the resulting proof before it is published in its final form. Please note that during the production process errors may be discovered which could affect the content, and all legal disclaimers that apply to the journal pertain. 


\title{
Differential modulation of the cytokine-induced MMP-9 / TIMP-1
}

\section{protease-antiprotease system by the mTOR inhibitor rapamycin}

\author{
Bashier Osman, El-Sayed Akool, Anke Doller, Roswitha Müller, Josef Pfeilschifter, and \\ Wolfgang Eberhardt*
}
pharmazentrum frankfurt/ZAFES, Institut für Allgemeine Pharmakologie und Toxikologie, Klinikum der Johann Wolfgang Goethe-Universität, Frankfurt am Main, Germany

\begin{abstract}
*Corresponding author: Wolfgang Eberhardt, Ph.D. pharmazentrum frankfurt/ZAFES, Institut für Allgemeine Pharmakologie und Toxikologie, Klinikum der Johann Wolfgang Goethe-Universität, Theodor-Stern-Kai 7, D-60590 Frankfurt am Main, Germany
\end{abstract}

phone: +49-69-6301-6953

fax: $\quad+49-69-6301-7942$

e-mail: w.eberhardt@em.uni-frankfurt.de 


\section{ABSTRACT}

The mTOR-inhibitor rapamycin is a potent drug used in many immunosuppressive and antiinflammatory therapeutic regimes. In renal transplantation despite its benefical roles rapamycin in some cases can promote renal fibrosis in the kidney but the underlying mechanisms are unknown. In this study, we tested for possible modulatory effects of rapamycin on the cytokine-triggered matrix metalloproteinase 9 (MMP-9)/ tissue inhibitor of metalloproteinase (TIMP)-1 protease-antiprotease system which is critically involved in renal inflammation and fibrosis. Treatment of rat mesangial cells (MC) with rapamycin dosedependently reduced the interleukin $1 \beta$ (IL-1 $1 \beta$ ) -triggered increase in gelatinolytic levels as demonstrated by zymography. The reduction in the extracellular MMP-9 content by rapamycin coincided with an attenuation in cytokine-induced steady-state MMP-9 mRNA levels. Conversely, rapamycin caused a dose-dependent increase in cytokine-evoked TIMP-1 expression in a Smad binding element (SBE) -dependent manner. Surprisingly, the attenuation of MMP-9 mRNA levels by rapamycin is accompanied by a potentiation of IL-1 $\beta$ - induced MMP-9 promoter activity in which the stimulatory effects by rapamycin are mainly attributed to a proximal AP-1 binding site. Furthermore, the rapamycin-dependent potentiation of MMP9 expression is accompanied by an amplification of cytokine-triggered activities of nuclear factor $\kappa \mathrm{B}(\mathrm{NF}-\mathrm{\kappa B})$ and activator protein 1 (AP-1) transcription factors. Importantly, rapamycin-triggered increase in MMP-9 promoter activity is fully impaired when we used a MMP-9 reporter construct which is under the additional control of the $3^{\prime}$ untranslated region (3'-UTR) of MMP-9. Collectively, these data imply that rapamycin inhibits the cytokineinduced MMP-9 mainly through posttranscriptional events and thereby exerts profibrotic activities. 
1 posttranscriptional gene regulation 


\section{Introduction}

In order to avoid calcineurin inhibitor (CNI)-induced nephrotoxicity and the occurrence of chronic nephropathy the macrocyclic lactone rapamycin (sirolimus) has firmly been established as a potent immunosuppressive and antiinflammatory drug in CNI-free treatment regimes $[1,2]$. In pharmacological terms, rapamycin acts through binding to the immunophilin FK binding protein 12 (FKBP12) and thereby inhibits the activity of the mammalian target of rapamycin (mTOR), a serine/threonine kinase which is critically involved in the regulation of protein biosynthesis and cell cycle progression [1]. Although many studies demonstrated potent antiinflammatory and antifibrotic effects of rapamycin, some recent studies have additionally implicated a certain nephrotoxic potential of rapamycin especially when given in combination with high doses of CNIs $[3,4]$, similar to CNIs, activates fibrogenic Smad signalling cascades via a direct and rapid activation of latent TGF $\beta$ by a mechanism which involves a generation of reactive oxygen species (ROS) [5]. Activation of Smad transcription factors is concomitant with an expression of TGF $\beta$-controlled genes including fibrogenic factors such as connective tissue growth factor (CTGF) and plasminogen activator inhibitor (PAI-1) [5]. Tissue fibrosis is histologically characterized by an excessive extracellular matrix (ECM) deposition [6,7]. Besides, the increased synthesis of ECM components, expansion of ECM unequivocally may also result from an insufficient matrix turnover. Physiologically, the degradation of ECM proteins is exerted by proteases including the matrix metalloproteases (MMPs) and plasminogen, which inturn are controlled by the balance of plasminogen activators (PAs) and plasminogen activator inhibitors (PAIs) and tissue inhibitors of matrix metalloproteinases (TIMPs). Disturbances in ECM turnover are often caused by a reduction in MMP expression and are worsened by an increased synthesis of the above mentioned intrinsic protease inhibitors $[8,9]$. Many studies could demonstrate that IL-1 $\beta$ is one of the major 
inducer of MMP-9 [10-12]. In renal MC, the cytokine-induced expression of MMP-9, one of the most abundant MMPs in the kidney, is transcriptionally inhibited by glucocorticoids and cyclosporin A (CsA) mainly through a negative interference with the proinflammatory and stress-inducible transcription factors activator protein-1 (AP-1) and nuclear factor $\kappa \mathrm{B}(\mathrm{NF}-\kappa \mathrm{B})$ $[12,13]$. Importantly, in rat MC corresponding binding sites located within a $1.3 \mathrm{~kb}$ upstream promoter region are indispensable for transcriptional activation of MMP-9 by proinflammatory cytokines $[12,14]$. The control of MMP-9 is complex since in addition to the regulation of MMP-9 transcription and modulation of extracellular activity by TIMPs, MMP-9 is furthermore adjusted by posttranscriptional events namely by alterations in MMP-9 mRNA stability [15,16] and/or changes in MMP-9 translation [17-20]. Structurally, AU-rich elements (AREs) in the $3^{\prime}$ untranslated region (3'-UTR) of the MMP-9 gene were reported as important cis-regulatory elements for posttranscriptional regulation of MMP-9 expression [15,19]. With respect to our previous finding demonstrating that rapamycin similarly to $\mathrm{CNI}$, can promote profibrogenic signalling in renal $\mathrm{MC}$, we tested whether rapamycin would exert a similar fibrogenic potential when added under proinflammatory conditions as simulated by the

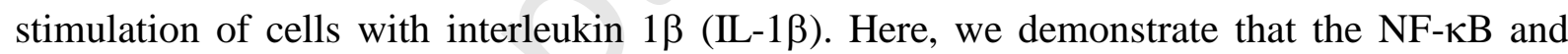
AP-1-triggered amplification of MMP-9 by rapamycin is counterbalanced and finally dominated by inhibitory effects via the 3'-UTR of MMP-9 mRNA. 


\section{Materials and Methods}

\subsection{Cell culture and reagents}

Rat glomerular MC were cultured as described [21]. Serum-free preincubations were performed in DMEM supplemented with $0.1 \mathrm{mg} / \mathrm{ml}$ of fatty acid-free bovine serum albumin (BSA) for $24 \mathrm{~h}$ before the cytokine was added. All cell culture media and supplements were purchased from Life-Technologies (Karlsruhe, Germany). For experiments 3.0-5.0 x $10^{6}$ of MC per 10-cm culture dish were used between passages 12 and 19. Determination of cell numbers was done by use of a Neubauer chamber.

Human recombinant IL-1 $\beta$ was from Cell Concept (Umkirch, Germany). Rapamycin and Actinomycin D (from Streptomyces species) were purchased from Calbiochem (Schwalbach, Germany). Antibodies against p65, HDAC-1, I $\kappa \mathrm{B} \alpha$ as well as the anti-rabbit and anti-mouse horseradish peroxidase-linked IgGs were purchased from Santa Cruz Biotechnology (Heidelberg; Germany). Antibodies against phosphorylated (Ser 63) c-Jun, phosphorylated Smad 2, total c-Jun and total Smad 4 were obtained from Cell Signaling (Frankfurt am Main, Germany). The anti $\beta$-actin antibody was from Sigma-Aldrich (Deisenhofen, Germany). Radiochemicals were purchased from Perkin Elmer (Rodgau Jüdesheim, Germany); the ECL system and Hyperfilm were purchased from Amersham Pharmacia Biotech (Freiburg, Germany).

\subsection{SDS-PAGE zymography}

Assessment of gelatinolytic MMP-9 content of proteins from cellular supernatants was performed as described previously [22]. Proteins with gelatinolytic content were visualized as areas of lytic activity on an otherwise blue gel [23]. Migration properties of proteins were determined by comparison with that of prestained PageRuler ${ }^{\mathrm{TM}}$ protein ladder (MBI 
Fermentas, St. Leon-Rot, Germany). Photographs of the gels were scanned by an imaging densitometer system from Bio Rad Laboratories (München, Germany).

\subsection{Determination of TIMP-1 antigen levels in conditioned media}

Levels of TIMP-1 antigens in cell culture supernatants were quantified by the Quantikine immunoassay kits from R\&D Systems raised against rat TIMP-1 (Wiesbaden-Nordenstadt, Germany). Confluent MC (1.0 to $1.5 \times 10^{6}$ cells) on six-well plates were preincubated in DMEM without FCS for 24 hours and stimulated with or without agents for the indicated time periods. $20 \mu \mathrm{l}$ of conditioned media were directly transferred to the microtest strip wells of the ELISA plate. All further procedures were performed following the manufacturer's instructions. The absorbances at $450 \mathrm{~nm}$ were measured in a microtest plate spectrophotometer and antigen levels were determined by appropriate calibration curves.

\section{4. cDNA clones and plasmids}

cDNA inserts for rat MMP-9 and TIMP-1 were generated as described previously [22]. A cDNA insert from mouse 18S rRNA was from Ambion (Austin, TX, USA). Cloning of a 1.3 $\mathrm{kb}$ fragment of the 5'-flanking region of the rat MMP-9 gene was described previously [12]. Introduction of double-point mutations into the NF- $\mathrm{BB}$ site of the pGL3-MMP-9 promoter vector to generate pGL3-MMP-9 $4 \mathrm{NK}-\kappa \mathrm{B}$ as well as the mutation of either a proximal or a distal lying AP-1 binding site to generate pGL3-MMP-9 $\triangle \mathrm{AP}-1 /-87$ or pGL3-MMP-9 $\Delta \mathrm{AP}-1 /$ 504, respectively, was accomplished as described previously [12]. A $0.6 \mathrm{~kb}$ promoter fragment of the rat wild-type TIMP-1 gene (pGL-3-TIMP-1) and mutanted constructs bearing a quadruple point mutation in a putative SBE (pGL-3-TIMP-1 $\Delta$ SBE) are described by Akool et al. [24]. The $3^{\prime}$-UTR sequence of the rat MMP-9 gene and a luciferase construct which in 
addition to the $1.3 \mathrm{~kb} 5$ 'promoter region of MMP-9 contains the $3^{\prime}$-UTR of the MMP-9 gene (pGL3-MMP-9/3'-UTR) was generated as described previously [15].

\subsection{Reporter gene assays}

Transient transfections of MC were performed using the Effectene reagent (Quiagen, Hilden, Germany). Transfections were performed following the manufacturer's instructions. The transfections were done as triplicates and repeated at least three times to ensure reproducibility of the results. Transfection with pRL-CMV coding for Renilla luciferase was used for control of the transfection efficiency. Luciferase activities were measured with the dual reporter gene system (Promega) using an automated chemoluminescence detector (Berthold, Bad Wildbad, Germany).

\subsection{Northern blot analysis}

Total cellular RNA was extracted from MC using the Tri reagent (Sigma-Aldrich Chemie, Taufkirchen, Germany) and RNA was hybridized following standard protocols as described previously [22].

\subsection{Real-time RT-PCR}

Two-step real-time PCR was performed using a Taqman (ABI 7500) from Perkin Elmer. The mRNA levels for MMP-9, elongation factor (EEF)-2 and GAPDH were determined by using a protocol according to the "hot start" real-time PCR procedure with "Quanti-Tec" SYBR green (Qiagen, Hilden, Germany). Total RNA was extracted using the Tri reagent and reverse transcription was performed using $0.5 \mu \mathrm{g}$ of total RNA and reverse transcriptase from Invitrogen (Invitrogen, Karlsruhe, Germany) with random hexamer primers. The following oligonucleotides were used for PCR: 
MMP-9 forward: 5'-ACGTGGGCAAATTCCAAACCTT-3' $\quad$; MMP-9 reverse: 5'-
AAGGCGTGTGCCAGTAGACCA-3’;
EEF-2
forward:
$5^{\prime}-$

GACATCACCAAGGGTGTGCA-3'; EEF-2 reverse: 5'-GCGGTCAGCACACTGGCATA-

3’; GAPDH forward: 5'-CACCATCTTCCAGGAGCGAG-3'and GAPDH reverse: 5'GCAGGAGGCATTGCTGAT-3'. The C(T) values of MMP-9 mRNA levels were normalized to the $\mathrm{C}(\mathrm{T})$ values of either GAPDH or EEF-2 mRNA within the same sample.

\title{
2.8. Electrophoretic Mobility Shift Assay (EMSA)
}

Preparation of crude nuclear extracts from cultured MC and subsequent EMSA was performed as described [14]. The sequences of the double-stranded oligonucleotides used for EMSA were derived from the rat MMP-9 promoter sequence (GenBank accession no. AJ 438266) and were as follows:

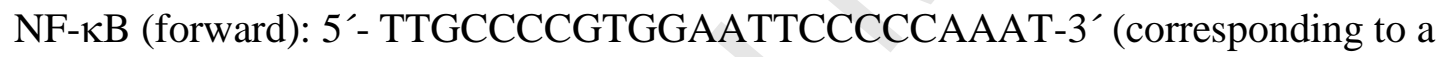
promoter region from -569 to -546$)$;

\begin{abstract}
AP-1 (forward): 5'-CACACACCCTGAGTCAGCGTAAGCCTGGAGGG-3'(corresponding to a promoter region from -98 to -65 ). Binding reactions were performed for $45 \mathrm{~min}$ on ice with $5 \mu \mathrm{g}$ of protein in $20 \mu \mathrm{l}$ of binding buffer containing 4\% Ficoll, $20 \mathrm{mM}$ HEPES (pH 7.9), $50 \mathrm{mM} \mathrm{KCl}, 1 \mathrm{mM}$ EDTA, $1 \mathrm{mM}$ DTT, $1 \mathrm{mM}$ PMSF, $0.25 \mathrm{mg} / \mathrm{ml}$ BSA, $2 \mu \mathrm{g}$ of poly(dI-dC), and 30,000-50,000 cpm of ${ }^{32} \mathrm{P}$-labeled oligonucleotide. The DNA-protein complexes were separated from unbound oligonucleotide by electrophoresis through native 5\% polyacrylamide geles using $0.5 \mathrm{x}$ Tris-borate-EDTA.
\end{abstract}

For supershift analysis, $2 \mu 1$ of supershift antibody was preincubated for 1 hour at room temperature with the nuclear extracts before the radioactively labeled oligonucleotide was added to the binding reaction. 


\subsection{Western blot analysis}

For detection of phosphorylated and total JNK whole cell lysates were prepared as described previously [12]. Western blot analysis was performed by standard procedures. $50 \mu \mathrm{g}$ of crude nuclear cell extracts were used for the assessment of nuclear import of p65-NF-kB.

Cytoplasmic levels of I $\mathrm{B}$ were analyzed using 50-100 $\mu \mathrm{g}$ of total protein from the corresponding cytoplasmic fractions. To ensure an equal sample loading of nuclear proteins the blots were stained with Ponceau-S.

\subsection{Statistical analysis}

Results are expressed as means \pm SD. Statistical analysis was performed using the Student's ttest and the analysis of variance (ANOVA) test for significance. The data are presented as relative induction compared to control conditions $(*)$ or compared to IL-1 $\beta$-stimulated values $(\#)$. P values $\leq 0.05(*)(\#), \leq 0.01(* *)(\# \#)$, and $\leq 0.001(* * *)(\# \# \#)$ were considered significant. 


\section{Results}

\subsection{Rapamycin reduces the cytokine-induced activity and $m R N A$ steady-state level of MMP-9}

Previously, we demonstrated that the immunosuppressive drug CsA, in contrast to tacrolimus (FK506), inhibits the cytokine-induced expression of MMP-9 in renal MC [13]. Here, we tested whether the mTOR kinase inhibitor rapamycin, another immunosuppressant with an overall lower nephrotoxic potential than CNIs, exerts a similar modulatory effect on MMP-9. Although rapamycin binds to the the same intracellular receptor as tacrolimus, i.e. the FKBP12, its immunosuppressive action is not mediated by an inhibition of calcineurin [1]. To evaluate possible modulatory effects of rapamycin on the extracellular activity of MMP-9, MC were treated with IL-1 $\beta(2 \mathrm{nM})$ for 24 hours in the presence of different concentrations of rapamycin (Fig. 1A). The gelatinolytic content of conditioned media was tested by zymography using gelatin as a substrate. As depicted in Fig. 1A, supernatants of MC under stimulatory conditions contain MMP-2 and MMP-9 with their characteristic migration properties at 68, $72 \mathrm{kDa}$ (MMP-2) and $92 \mathrm{kDa}$ (MMP-9), respectively. Rapamycin dosedependently attenuated the extracellular IL-1 $\beta$-evoked MMP-9 levels with a maximal reduction seen at $100 \mathrm{ng} / \mathrm{ml}$, whereas it had no effect on the constitutive levels of latent and active MMP-2, represented by the two lytic bands at 68 and $72 \mathrm{kDa}$, respectively (Fig. 1A).

To further investigate whether the reduction in the lytic content of MMP-9 by rapamycin is due to a reduction in the corresponding MMP-9 mRNA levels, we performed Northern blot analysis using a cDNA probe from the rat MMP-9 gene [22]. Again, MC were stimulated for 24 hours with $\mathrm{IL}-1 \beta(2 \mathrm{nM})$ in the presence of different concentrations of rapamayin as indicated in Fig. 1B. Concomitantly with the inhibitory effect on gelatinolytic MMP-9 content, rapamycin dose-dependently attenuated the IL-1 $\beta$-induced MMP-9 mRNA level and a maximal inhibition of approximately $60 \%$ was obtained when rapamycin was used at 100 
ng/ml (Fig. 1B). Again, rapamycin was unable to induce MMP-9 mRNA when given alone (Fig. 1B). These data indicate that alterations in the cytokine-induced extracellular MMP-9 content by rapamycin predominantly result from reduced steady-state MMP-9 mRNA levels.

\subsection{Rapamycin induces the expression of TIMP-1}

In a next step, we evaluated whether rapamycin, in addition to MMP-9, could influence the cytokine-induced levels of the intrinsic MMP-9 inhibitor TIMP-1. To this end, MC were stimulated with either IL-1 $(2 \mathrm{nM})$, in the absence or presence of rapamycin and corresponding cell supernatants were collected after 4,8 and 24 hours for assessment of extracellular TIMP-1 antigen levels by specific ELISA. Treatment of MC with either IL-1 $\beta$ or with rapamycin caused a significant increase in the amount of extracellular TIMP-1 at 8 and 24 hours of stimulation (Fig. 2A). The combination of both stimuli resulted in an additive increase in TIMP-1 release and was most prominently seen at 24 hours of stimulation (Fig. 2A). In order to test whether alterations in extracellular TIMP-1 contents by rapamycin were attributed to changes in TIMP-1 mRNA levels, we performed Northern blot analysis by using a cDNA probe from the rat TIMP-1 gene [22]. Since the stimulatory effects of rapamycin were most obvious after $24 \mathrm{~h}$, we chose this incubation time for an assessment of steady-state TIMP-1 mRNA levels. As shown in Fig. 2B, rapamycin dose-dependently enhanced the IL$1 \beta$-induced steady-state TIMP-1 mRNA levels and caused a parallel increase in extracellular TIMP-1. Rapamycin caused a moderate increase in basal TIMP-1 mRNA levels when given alone. In a next approach, we assessed whether the rapamycin-mediated increase in cytokineinduced TIMP-1 mRNA levels rely on transcriptional events. For this purpose we tested the inducibility of a reporter construct bearing $0.6 \mathrm{~kb}$ of an upstream promoter region of the rat TIMP-1 gene [24]. Transient transfection of MC with pGL-TIMP-1 was followed by a 24 hour treatment with $\mathrm{IL}-1 \beta(2 \mathrm{nM})$ in the absence or presence of rapamycin before cells were 
lysed for assessment of luciferase activity. As shown in Fig. 2C, stimulation with either IL-1 $\beta$ or rapamycin caused a weak increase in TIMP-1 promoter activity and further increased in an additive manner when both stimuli were applied in combination (Fig. 2C, upper panel). These data are reminiscent of the regulation of another protease inhibiter, plasminogen activator inhibitor-1 (PAI-1) by rapamycin involving the TGF 3 -Smad signaling cascade [5].

Therefore, we tested for an activation of the Smad signaling cascade by assessment of nuclear Smad 2 and Smad 4. Importantly, IL-1 $\beta$ alone caused a moderate increase in phospho-Smad 2 levels and this increase was dose-dependently augmented by rapamycin. Concomitantly, nuclear Samd 4 contents was dose-dependently increased by rapamycin (Fig. 2C, lower panel).

To additionally test whether the activation of Smads plays a functional role in TIMP-1 regulation, we tested whether induction of TIMP-1 promoter activity by rapamycin depends on a functional Smad-binding element (SBE). To this end, the inducibility of a TIMP-1 promoter construct (pGL-3-TIMP $\triangle \mathrm{SBE}$ ) bearing a point mutation in SBE was assessed [24]. As shown in Fig. 2D, mutation of SBE completely impaired promoter inducibility by rapamycin (black bars) thus supporting the notion that the rapamycin-triggered induction of TIMP-1 occurs via activation of Smads and their binding to a corresponding promoter element.

\subsection{Rapamycin amplifies the cytokine-induced activity of p65 and c-Jun}

Previously, we have demonstrated that the inhibition of MMP-9 by cyclosporin A is mainly attributable to an inhibition of the proinflammatory transcription factors NF-kB and AP-1 [13]. To test for a possible involvement of either transcription factor in the rapamycinmediated suppression of MMP-9, we assessed nuclear extracts from stimulated MC for NF$\kappa \mathrm{B}$ and AP-1 activities. We monitored nuclear translocation of the NF- $\kappa \mathrm{B}$ subunit $\mathrm{p} 65$ and 
phosphorylation of nuclear c-Jun by Western blot analysis, since both events are indicative for an activation of the transcription factors. We chose a short stimulation of $30 \mathrm{~min}$ as the activation of both factors by cytokines achieved a maximal response at this time point [13]. Stimulation of MC with IL-1 $\beta$ was followed by a clear increase in phospho-c-Jun levels and surprisingly, the cytokine-evoked increase in phosphorylated c-Jun was further amplified with increasing doses of rapamycin without any effect on basal phospho-c-Jun levels (Fig. 3A). By contrast, the nuclear content of c-Jun remained constant independently of the stimulus applied (Fig. 3A). In parallel to the increase in nuclear c-Jun phosphorylation, rapamycin caused a dose-dependent augmentation of the nuclear p65 import triggered by IL-1 $\beta$ but had only a moderate stimulatory effect on nuclear p65 translocation when given alone (Fig. 3A). Corresponding to the increased nuclear import of p65, the cytoplasmic degradation of the inhibitor of $\kappa \mathrm{B}$ (IкB) achieved by IL-1 $\beta$ was dose-dependently intensified by rapamycin resulting in a complete disappearance of IKB at the highest does of rapamycin tested (100 ng/ml) (Fig. 3A, lower panel).

Consistently, EMSA with a gene-specific NF-kB oligonucleotide demonstrated that rapamycin caused an amplification of the cytokine-evoked binding affinity of a slowmigrating and IL-1 $\beta$-inducible complex (Fig. 3B, upper left panel) which mainly consists of p65 as demonstrated by supershift analysis (Fig. 3B, upper right panel). The amplification of NF- $\mathrm{KB}$ binding affinity by rapamycin was most clearly seen in those experiments with a moderate NF-KB induction (Fig. 3B, upper panel) indicating that rapamycin mainly acts via an amplification of cytokine-evoked NF-kB signalling.

In contrast to NF- $\mathrm{kB}$, the constitutive DNA-binding to a proximal AP-1 site at $-87 /-81$ was not affected by IL-1 $\beta$, but was intensified by rapamycin (Fig. 3B, lower left panel). Supershift analysis showed that the rapamycin sensitive complex mainly consists of c-Jun (Fig. 3B, lower right panel) which is consistent with results from Western blot analysis (Fig. 3A.) 
Taken together, these results indicate that rapamycin contrary to its well established antiinflammatory properties and in a contrast to CsA, amplifies the cytokine-induced activities of NF- $\mathrm{BB}$ and AP-1 transcription factors.

\subsection{Rapamycin amplifies $I L-1 \beta$-triggered $M M P-9$ promoter activity via $A P-1$ and $N F-\kappa B$}

To further investigate whether the inhibition of cytokine-induced MMP-9 mRNA levels by rapamycin is reflected by an inhibition in MMP-9 promoter activity, we performed reporter gene assays using a $1.3 \mathrm{~kb}$ MMP-9 promoter fragment ("pGL3-MMP-9", Fig. 4A). This promoter portion is sufficient for the induction of MMP-9 by IL-1 $\beta$ and critically depends on AP-1 and NF- $\kappa$ B binding sites [12]. Transient transfection of MC with pGL3-MMP-9 was followed by a $24 \mathrm{~h}$ treatment with $\mathrm{IL}-1 \beta(2 \mathrm{nM})$, rapamycin $(100 \mathrm{ng} / \mathrm{ml})$ or both in combination and subsequently, cells were assayed for luciferase activity. Similar to the amplification of AP-1 and NF- $\kappa$ B binding, the IL-1 $\beta$-induced increase in MMP-9 promoter activity was significantly amplified by rapamycin (Fig. 4B "pGL3-MMP-9"). In addition, rapamycin significantly increased MMP-9 promoter activity when given alone (Fig. 4B). Based on our previous finding that $\mathrm{AP}-1$ and $\mathrm{NF}-\kappa \mathrm{B}$ promoter elements are indispensable for MMP-9 promoter activation by $\mathrm{IL}-1 \beta$, we furthermore tested for a functional role of corresponding promoter elements in the amplification of MMP-9 promoter activity by rapamycin. To this end, we assayed the luciferase activities of pGL3-MMP-9 constructs bearing single point mutations in the binding sites of NF- $\mathrm{KB}$ or AP-1 as depicted in Fig. 4A.

In a full agreement with our previous findings [12], mutation of either the NF- $\kappa B$ binding site (pGL-3-MMP-9 $\Delta$ NF- $\kappa$ B) or of a distal AP-1 site (pGL3-MMP-9 $\Delta$ AP-1/-504) prevented the cytokine induction of pGL-MMP-9 by IL-1 $\beta$ and impaired the stimulatory effect by rapamycin (Fig. 4B). These data suggest that both transcription factor binding sites are indispensable for induction of MMP-9 promoter activity by IL-1 $\beta$. Most intriguingly, a mutation of the 
proximal AP-1 site at -87 (pGL3-MMP-9 $\Delta$ AP-1/-87) specifically prevented MMP-9 promoter activation by rapamycin but did not interfere with IL-1 $\beta$ inducibility (Fig. 4C). This also fits to the AP-1 EMSA performed with a probe encompassing the corresponding promoter region (Fig. 3B, lower panels) and corroborates that the proximal AP-1 binding site at -87 is mainly involved in the amplification of MMP-9 promoter activity by rapamycin but irrelevant for cytokine induction of MMP-9.

\subsection{Rapamycin-triggered amplification of MMP-9 is prevented in the presence of the $3^{\prime}-U T R$}

The discrepant findings from Northern blot analysis and reporter gene assays imply that rapamycin may mask the positive effects on MMP-9 transcription and actually inhibit MMP-9 expression via additional posttranscritpional mechanisms. Negative effects on mRNA stability by rapamayin have been reported for the IL-3 mRNA [25]. Importantly, we previously demonstrated that the rat MMP-9 is regulated via changes in mRNA stability [15]. In order to test whether rapamycin may affect the stability of MMP-9 mRNA, we performed actinomycin D experiments. MC were stimulated for 24 hours with IL-1 $\beta(2 \mathrm{nM})$ before transcription was blocked by actinomycin D $(5 \mu \mathrm{g} / \mathrm{ml})$. Subsequently, cells were treated in the presence or absence of rapamycin $(100 \mathrm{ng} / \mathrm{ml})$ for further 12 or 24 hours, respectively. MMP-9 mRNA levels showed an approximate 50\% reduction at 12 hours but, importantly, rapamycin had no significant modulatory effect on the decay of MMP-9 mRNA (Fig. 5A). Unfortunately, coincubations with actinomycin-D and rapamycin longer than 12 hours resulted in a strong cell death which probably is due to a simultaneous inhibition of transcription and translation (data not shown). In addition, actinomycin D is known to affect nucleo-cytoplasmic HuR shuttling and thereby might also influence the stability of MMP-9 mRNA in renal MC. Therefore, as an alternative approach, we chose a Luciferase reporter construct which in addition to the $5^{\prime}$ promoter region is under the control of the $3^{\prime}$-UTR of the MMP-9 gene 
(“pGL3-MMP-9/3'-UTR") as indicated in Fig. 5B. We and others have demonstrated that regulatory sequences within the $3^{\prime}$-UTR are functionally relevant for posttranscriptional control of MMP-9 [15,19]. Indeed, transient transfection of MC with this reporter construct revealed that the stimulatory effects of rapamycin shown in Fig. 4B were totally abrogated when the reporter was under the additional control of the $3^{\prime}$-UTR of MMP-9 (Fig. 5B). These results document that the inducible effects on cytokine-triggered MMP-9 expression by rapamycin are blunted in the presence of the $3^{\prime}$-UTR of the MMP-9 gene. 


\section{Discussion}

In this report, we provide evidence that the immunsuppressive drug rapamycin potently inhibits cytokine-induced expression and activity of MMP-9 through different mechanisms. On the one hand, we demonstrate that rapamycin amplifies the cytokine-induced extracellular content of TIMP-1, the intrinsic inhibitor of MMP-9, via a drug-dependent activation of TIMP-1 promoter activity involving a Smad binding element (SBE) (Fig. 2C). On the other hand, we observed a significant reduction in the steady-state MMP-9 mRNA levels by rapamycin accompanied by a dose-dependent attenuation in MMP-9 gelatinolytic levels (Fig. 1). However, contrary to the reduction of cytokine-induced MMP-9 expression, reporter gene assays with a $1.3 \mathrm{~kb}$ MMP-9 promoter construct revealed a potentiation in cytokine-induced promoter activity. The latter amplification is attributable to a proximal AP-1 binding site (Fig. 4C). Consistent with the rapamycin-triggered increase in MMP-9 promoter activity, we observed a dose-dependent potentiation of the cytokine-evoked transcription factors c-Jun and NF- $\kappa \mathrm{B}$ by rapamycin (Fig. 3). These data implicate that the transcription factors which are indispensably required for MMP-9 transcription [12,26] are also targeted by rapamycin (Fig. 4). In line with this observation, previous studies have demonstrated that mTOR inhibition by rapamycin via activation of the c-Jun N-terminal kinase (JNK) induces a rapid c-Jun phosphorylation which in turn is functionally implicated in p53-independent apoptosis [27] and in the transcriptional upregulation of MMP-1 [28].

The elevation in MMP-9 promoter activity and the corresponding AP-1 and NF- $\mathrm{BB}$ activities by rapamycin contrast to the negative effects we have observed with CsA [13]. According to the regulatory role of JNK in activating AP-1 it is tempting to speculate that a differential modulation of JNK by CsA and rapamycin is causally involved in their opposing effects on proinflammatory transcription factors and MMP-9 promoter activity. In addition, our data implicate that the antiinflammatory activities reported for rapamycin are not attributed to an 
inhibition of AP-1 and NF-אB. Moreover, our data exclude that the negative regulation of MMP-9 gene expression by rapamycin is caused by induction of the TGF $\beta /$ Smad cascade as has been demonstrated for the human MMP-9 gene [29]. The question whether regulatory promoter elements upstream of $-13 \mathrm{~kb}$ of the MMP-9 gene are negatively influenced by rapamycin is a subject of ongoing research in our laboratory. In view of the contradictory effects of rapamycin on MMP-9 mRNA levels and MMP-9 promoter activity, we postulated that the negative effects on MMP-9 by rapamycin may result from additional posttranscriptional events. Notably, we previously could demonstrate that several copies of destabilizing AU-rich elements (AREs) present in the 3'-UTR of rat MMP-9 gene are critically involved in the posttranscriptional regulation of MMP-9 [15,30,31].

The functional relvance of the 3'-UTR in rapaymcin dependent MMP-9 regulation is provided by the finding that stimulatory effects on MMP-9 promoter activity by rapamycin were fully impaired when the MMP-9 reporter gene was under the additional control of the $3^{\prime}$-UTR of MMP-9 (Fig. 5B).

In line with our observations a posttranscriptional regulation by rapamycin has been convincingly demonstrated for IL-3 mRNA [25]. Despite of the IL-3 encoding mRNA, destabilizing effects by rapamycin have furthermore been described for other mRNAs including those coding for collagen type 1 [32] and collagen type 3A1 [28] as well as cyclin $\mathrm{D}_{3}$ mRNA [30]. Similar to IL-3 mRNA, the destabilizing effect of rapamycin on cyclin $\mathrm{D}_{3}$ mRNA is attributed to two canonical AREs in the $3^{\prime}$-UTR of an mRNA [33].

Our finding that the blockade of transcription by actinomycin D experiments showed no changes in MMP-9 mRNA decay implies that rapamycin may act via the induction of amRNA destabilizing factor (Fig. 5A). Prominent candidates for mRNA binding proteins with a predominantly destabilizing effect on ARE-mRNAs are polyA/poly U-binding degradation factor (AUF) [34], tristetraprolin (TTP) [35] and the K-homology-type splicing regulatory 
protein (KSRP) [36]. Further studies are needed to test whether the expression of one of these factors is modulated by rapamycin. Alternatively, rapamycin may induce the expression of a miRNA which specifically targets MMP-9 mRNA. However, to the best of our knowledge, a contribution of miRNAs in the suppression of MMP-9 expression has not been described so far.

Functionally, the inhibition in collagen I expression by rapamycin may counteract an accumulation of extracellular matrix and thus counteract tissue fibrosis [28]. In contrast to these antifibrotic activities, we previously found that rapamycin via rapid induction of the canonical TGF $\beta$-Smad signalling cascade promotes profibrotic gene expression in rat MC [5]. The finding that rapamycin, in addition to induction of TIMP-1, directy interferes with the expression of MMP-9 further underscores the profibrotic potential by its activation of the canonical TGF $\beta$-Smad signaling pathway [5]. Unlike tissue fibrosis, an excessive degradation of ECM as a result of increased expression of matrix-metabolizing proteases is a hallmark of many inflammatory processes and functionally relevant for irreversible alterations of tissue architecture. In the kidney, apart from the general role in ECM remodelling, an excessive proteolytic degradation of collagen IV-containing basement membranes mainly by MMP-9, seems an important feature for the increased recruitment of moncytes and macrophages to the site of inflammation [6]. Proinflammatory cytokines such as TNF- $\alpha$ and IL-1 $\beta$ either produced by infiltrating immune cells, or by resident activated glomerular MC are among the most potent inducers of MMP-9 [12,22]. Besides its potent immunosuppressive and antiproliferative properties via mTOR kinase inhibition, the attenuation of cytokine-evoked MMP-9 by rapamycin may additionally contriubte to its anti-inflammatory and profibrotic activities $[28,37]$. Whether the rapamycin-mediated suppression of MMP-9 like the one evoked by $\mathrm{CsA}$ is independent of its primary immunosuppressive action needs further investigations. 
In summary, our study shows that the immunosuppressant rapamycin amplifies cytokineinduced NF-KB and AP-1 activation and subsequently on MMP-9 promoter activity. However, this response is counteracted by an inhibitory effect of rapamycin on the IL-1 $\beta$-induced MMP9 mRNA stability by targeting destabilizing elements in the 3 '-UTR of MMP-9 mRNA. Our study furthermore highlights the complex repertoire of regulatory events which in addition to mTOR inhibition are executed by rapamycin.

\section{Acknowledgements}

The authors acknowledge the financial support of grants from the Deutsche Forschungsgemeinschaft EB 257/3-1, EB 257/5-1, GRK1172 and EXC 147/1. 


\section{References}

[1] Faivre S, Kroemer G, Raymond E. Current development of mTOR inhibitors as anticancer agents. Nat Rev Drug Discov 2006;5:671-88.

[2] Saunders RN, Metcalfe MS, Nicholson ML. Rapamycin in transplantation: a review of the evidence. Kidney Int 2001;59:3-16.

[3] Shihab FS, Bennett WM, Yi H, Choi SO, Andoh TF. Sirolimus increases transforming growth factor-beta1 expression and potentiates chronic cyclosporine nephrotoxicity. Kidney Int 2004;65:1262-71.

[4] Ninova D, Covarrubias M, Rea DJ, Park WD, Grande JP, Stegall MD. Acute nephrotoxicity of tacrolimus and sirolimus in renal isografts: differential intragraft expression of transforming growth factor- $\beta 1$ and $\alpha$-smooth muscle actin. Transplantation 2004;78:338-44.

[5] Osman B, Doller A, Akool el-S, Holdener M, Hintermann E, Pfeilschifter J et al. Rapamycin induces the TGF $\beta 1 / \mathrm{Smad}$ signaling cascade in renal mesangial cells upstream of mTOR. Cell Signal 2009;21:1806-17.

[6] Eddy AA. Molecular insights into renal interstitial fibrosis. J Am Soc Nephrol 1996; 7:2495508

[7] Eddy AA, Fogo AB. Plasminogen activator inhibitor-1 in chronic kidney disease: evidence and mechanisms of action. J Am Soc Nephrol 2006;17:2999-12.

[8] Nagase H, Woessner JF Jr. Matrix metalloproteinases. J Biol Chem 1999;274:21491-4.

[9] Lenz O, Elliot SJ, Stetler-Stevenson WG. Matrix metalloproteinases in renal development and disease. Am Soc Nephrol 2000;11:574-81.

[10] Van Ranst M, Norga K, Masure S, Proost P, Vandekerckhove F, Auwerx J, Van Damme J, Opdenakker G. The cytokine-protease connection: identification of a 96-kD THP-1 gelatinase and regulation by interleukin-1 and cytokine inducers.Cytokine 1991;3:231-9.

[11] Opdenakker G, Masure S, Grillet B, Van Damme J. Cytokine-mediated regulation of human leukocyte gelatinases and role in arthritis. Lymphokine Cytokine Res 1991;10:317-24.

[12] Eberhardt W, Schulze M, Engels C, Klasmeier E, Pfeilschifter J. Glucocorticoidmediated suppression of cytokine-induced matrix metalloproteinase- 9 expression in rat mesangial cells: involvement of nuclear factor- $\kappa \mathrm{B}$ and Ets transcription factors. Mol Endocrinol 2002;16:1752-66. 
[13] Doller A, Akool el-S, Müller R, Gutwein P, Kurowski C, Pfeilschifter J et al. Molecular mechanisms of cyclosporin A inhibition of the cytokine-induced matrix metalloproteinase-9 in glomerular mesangial cells. J Am Soc Nephrol 2007;18:581-92.

[14] Eberhardt W, Huwiler A, Beck KF, Walpen S, Pfeilschifter J. Amplification of IL-1 $\beta$ induced matrix metalloproteinase- 9 expression by superoxide in rat glomerular mesangial cells is mediated by increased activities of NF- $\kappa \mathrm{B}$ and activating protein-1 and involves activation of the mitogen-activated protein kinase pathways. J Immunol 2000;165:5788-7.

[15] Akool el-S, Kleinert H, Hamada FM, Abdelwahab MH, Förstermann U, Pfeilschifter J et al. Nitric oxide increases the decay of matrix metalloproteinase $9 \mathrm{mRNA}$ by inhibiting the expression of mRNA-stabilizing factor HuR. Mol Cell Biol 2003;23:4901-16.

[16] Iyer V, Pumiglia K, DiPersio CM. Alpha3beta1 integrin regulates MMP-9 mRNA stability in immortalized keratinocytes: a novel mechanism of integrin-mediated MMP gene expression. J Cell Sci 2005;118:1185-95.

[17] Jiang Y, Muschel RJ. Regulation of matrix metalloproteinase-9 (MMP-9) by translational efficiency in murine prostate carcinoma cells. Cancer Res 2002;62:1910-4.

[18] Sehgal I, Thompson TC. Novel regulation of type IV collagenase (matrix metalloproteinase- 9 and -2 ) activities by transforming growth factor- $\beta 1$ in human prostate cancer cell lines. Mol Biol Cell 1999;10:407-16.

[19] Fähling M, Steege A, Perlewitz A, Nafz B, Mrowka R, Persson PB et al. Role of nucleolin in posttranscriptional control of MMP-9 expression. Biochim Biophys Acta 2005;1731:32-40.

[20] Jespersen C, Doller A, Akool el-S, Bachmann M, Müller R, Gutwein P, et al. Molecular mechanisms of nitric oxide-dependent inhibition of TPA-induced matrix metalloproteinase-9 (MMP-9) in MCF-7 cells. J Cell Physiol 2009;219:276-87.

[21] Pfeilschifter J, Vosbeck K. Transforming growth factor $\beta 2$ inhibits interleukin $1 \beta$ - and tumour necrosis factor $\alpha$ induction of nitric oxide synthase in rat renal mesangial cells. Biochem Biophys Res Commun 1991;175:372-9.

[22] Eberhardt W, Beeg T, Beck KF, Walpen S, Gauer S, Böhles H et al. Nitric oxide modulates expression of matrix metalloproteinase- 9 in rat mesangial cells. Kidney Int 2000;57:59-69.

[23] Van den Steen PE, Dubois B, Nelissen I, Rudd PM, Dwek RA, Opdenakker G. Biochemistry and molecular biology of gelatinase B or matrix metalloproteinase-9 (MMP-9). Crit Rev Biochem Mol Biol 2002;37:375-536. 
[24] Akool el-S, Doller A, Müller R, Gutwein P, Xin C, Huwiler A et al. Nitric oxide induces TIMP-1 expression by activating the transforming growth factor beta-Smad signaling pathway. J Biol Chem 2005;280:39403-16.

[25] Banholzer R, Nair AP, Hirsch HH, Ming XF, Moroni C. Rapamycin destabilizes interleukin-3 mRNA in autocrine tumor cells by a mechanism requiring an intact $3^{\prime}$ untranslated region. Mol Cell Biol 1997;17:3254-60.

[26] Yokoo T, Kitamura M. Dual regulation of IL-1 $\beta$-mediated matrix metalloproteinase-9 expression in mesangial cells by NF-kappa B and AP-1. Am J Physiol 1996;270:F12330.

[27] Huang S, Shu L, Dilling MB, Easton J, Harwood FC, Ichijo H et al. Sustained activation of the JNK cascade and rapamycin-induced apoptosis are suppressed by p53/p21(Cip1). Mol Cell 2003;11:1491-01.

[28] Poulalhon N, Farge D, Roos N, Tacheau C, Neuzillet C, Michel L et al. Modulation of collagen and MMP-1 gene expression in fibroblasts by the immunosuppressive drug rapamycin. A direct role as an antifibrotic agent? J Biol Chem 2006;281:33045-52.

[29] Ogawa K, Chen F, Kuang C, Chen Y. Suppression of matrix metalloproteinase-9 transcription by transforming growth factor $-\beta$ is mediated by a nuclear factor- $\mathrm{kB}$ site. Biochem J 2004;381:413-22.

[30] Huwiler A, Akool el-S, Aschrafi A, Hamada FM, Pfeilschifter J, Eberhardt W. ATP potentiates interleukin-1 beta-induced MMP-9 expression in mesangial cells via recruitment of the ELAV protein HuR. J Biol Chem 2003;278: 51758-69.

[31] Eberhardt W, Doller A, Akool el-S, Pfeilschifter J. Modulation of mRNA stability as a novel therapeutic approach. Pharmacol Ther 2007;114:56-73.

[32] Shegogue D, Trojanowska M. Mammalian target of rapamycin positively regulates collagen type I production via a phosphatidylinositol 3-kinase-independent pathway. J Biol Chem 2004;279:23166-75.

[33] Pallet N, Thervet E, Le Corre D, Knebelmann B, Nusbaum P, Tomkiewicz Cet al. Rapamycin inhibits human renal epithelial cell proliferation: effect on cyclin D3 mRNA expression and stability. Kidney Int 2005;67:2422-33.

[34] Zhang W, Wagner BJ, Ehrenman K, Schaefer AW, DeMaria CT, Crater D et al. Purification, characterization, and cDNA cloning of an AU-rich element RNA-binding protein, AUF1. Mol Cell Biol 1993;13:7652-65.

[35] Blackshear PJ. Tristetraprolin and other $\mathrm{CCCH}$ tandem zinc-finger proteins in the regulation of mRNA turnover. Biochem Soc Trans 2002;30:945-52.

[36] Gherzi R, Trabucchi M, Ponassi M, Ruggiero T, Corte G, Moroni C et al. The RNAbinding protein KSRP promotes decay of beta-catenin mRNA and is inactivated by PI3K-AKT signaling. PLoS Biol 2006;5:e5 
[37] Berthier CC, Wahl PR, Le Hir M, Marti HP, Wagner U, Rehrauer H, et al. Sirolimus ameliorates the enhanced expression of metalloproteinases in a rat model of autosomal dominant polycystic kidney disease. Nephrol Dial Transplant 2008;23:880-9. 


\section{Figure Legends}

Figure 1. Dose-dependent inhibition of IL-1 $\beta$-induced gelatinolytic MMP-9 contents (A) and steady-state MMP-9 mRNA levels (B) by rapamycin. Quiescent MC were either left untreated (-), or treated for $24 \mathrm{~h}$ with IL-1 $\beta(2 \mathrm{nM})$ in the absence (-) or presence of the indicated concentrations of rapamycin (Rapa) $(A): 10 \mu l$ of supernatants were subjected to SDS-PAGE zymography to assess the gelatinolytic levels of extracellular MMP-9. The migration properties of lytic bands, corresponding to inactive pro MMP-9 (92 kD), and the inactive and active forms of MMP-2 (72 and $68 \mathrm{kDa}$ respectively) were determined using standard molecular weight markers. A densitometrical analysis of MMP-9 gelatinolytic activities derived from equal cell numbers from three independent experiments is given at the right panel. Data represent means $\pm \mathrm{SD}(\mathrm{n}=3)$ and are represented as arbitrary units. $* * * P \leq$ 0.005 compared with control; ${ }^{\# \#} P \leq 0.01$, ${ }^{\# \# \#} P \leq 0.005$ versus IL-1 $\beta$-treated conditions. $(B)$. Northern blot analysis, showing the dose-dependent inhibition of IL-1 $\beta$-induced MMP-9 by rapamycin. Quiescent MC were stimulated as in (A). Total cellular RNA (20 $\mu \mathrm{g})$ was extracted and hybridized to a ${ }^{32} \mathrm{P}$-labeled cDNA insert from KS-MMP-9 for Northern blot analysis as described in "Materials and Methods". Equivalent loading of RNA was ascertained by rehybridization to a $18 \mathrm{~S}$ RNA probe. A densitometrical analysis of three independent experiments is shown at the right panel. Results are expressed as means $\pm S D(n=3)$ and are presented as \% of MMP-9 mRNA induced by IL-1 $\beta$ depicted as $100 \%$. $* * P \leq 0.005$ compared with control; ${ }^{\# \#} P \leq 0.01,{ }^{\# \# \#} P \leq 0.005$ compared with IL-1 $\beta$-treated conditions.

\section{Figure 2. Rapamycin upregulates TIMP-1 promoter activity and via a gene-specific SBE} increases TIMP-1 expression. (A). MC were treated with either vehicle, IL-1 $\beta$ (2 nM), rapamycin $(100 \mathrm{ng} / \mathrm{ml})$, or both in combination as indicated. After stimulation, $20 \mu \mathrm{l}$ of cell culture supernatants were subjected to Quantikine Immunoassay Kit for measurement of 
TIMP-1 antigen levels. Data represent means $\pm \mathrm{SD}(\mathrm{n}=4) . * P \leq 0.05, * * P \leq 0.01, * * * P \leq$ 0.005 compared with corresponding control levels. ${ }^{\#} P \leq 0.05,{ }^{\# \#} P \leq 0.01$ versus IL-1 $\beta$-treated conditions. $(B)$. Northern blot analysis, demonstrating a dose-dependent augmentation of IL$1 \beta$-induced TIMP-1 mRNA levels by rapamycin. Quiescent MC were stimulated with either vehicle $(-)$ or IL-1 $\beta(2 \mathrm{nM})(+)$ for $24 \mathrm{~h}$ in the presence of the indicated concentrations of rapamycin. Total cellular RNA $(20 \mu \mathrm{g})$ was extracted and hybridized to a ${ }^{32} \mathrm{P}$-labeled cDNA insert from KS-TIMP-1 for Northern blot analysis as described in "Materials and Methods". Equivalent loading of RNA was ascertained by rehybridization to a $18 \mathrm{~S}$ RNA probe. A densitometrical analysis of three independent experiments is shown at the right panel . Results are expressed as means $\pm S D(n=3)$ and are presented as TIMP-1 mRNA relative to $18 \mathrm{~S}$ rRNA. $* P \leq 0.05,{ }^{* * P} \leq 0.01$, compared with control; ${ }^{\#} P \leq 0.05,{ }^{\# \#} P \leq 0.01$ versus IL-1 $\beta$ treated conditions. (C, upper panel). Quiescent MC were transiently cotransfected with $0.4 \mu \mathrm{g}$ of pGL-TIMP-1 $(0.6 \mathrm{~kb})$ and with $0.1 \mu \mathrm{g}$ of pRL-CMV coding for Renilla luciferase. After overnight transfection, MC were left untreated (vehicle), or treated for 24 hours either with rapaymcin $(100 \mathrm{ng} / \mathrm{ml})$, or with $\mathrm{IL}-1 \beta(2 \mathrm{nM})$ in the absence or presence of the indicated concentrations of rapamycin. The values for beetle luciferase were related to values for Renilla luciferase and are depicted as relative light units (RLU). Data represent means \pm SD $(n=6) . * P \leq 0.05$ compared with control or versus ${ }^{\#} P \leq 0.05,{ }^{\# \#} P \leq 0.01 \mathrm{IL}-1 \beta$-stimulated values. $(C$, lower panel). Dose-dependent activation of Smad-2 and Smad-4 by rapamycin. Quiescent MC were stimulated for $30 \mathrm{~min}$ similar as described above. $30 \mu \mathrm{g}$ of nuclear extracts were successively probed with either an anti-phospho-Smad-2 antibody or, with an antibody directed against Smad-4. Loading of equal amounts of nuclear extracts was ascertained by reprobing the blots with an anti-HDAC-1 antibody. Westernblots are representative for three independent experiments giving similar results. (D). Subconfluent MC were transfected with $0.4 \mu \mathrm{g}$ of either pGL-TIMP-1 (white bars) or, alternatively, with the 
same promoter bearing a mutated SBE (pGL-TIMP-1 $\triangle \mathrm{SBE}$, black bars). Transfection of the plasmids was supplemented by a cotransfection with $0.1 \mu \mathrm{g}$ of RL-CMV, coding for Renilla luciferase as described in (C). After transient transfection MC were treated for 16 hours with either vehicle, IL-1 $\beta(2 \mathrm{nM})$, rapamycin $(100 \mathrm{ng} / \mathrm{ml})$ or $\mathrm{IL}-1 \beta$ plus rapamycin as indicated before extracted for total cell lysates and assayed for luciferase activities. Values for beetle luciferase were related to the values for Renilla luciferase and are depicted as relative light units (RLU). Data represent the means \pm S.D. $(n=6)$ of triplicate experiments. ${ }^{* *}, \mathrm{p} \leq 0.01$ compared with vehicle.

\section{Figure 3. Amplification of IL-1 $\beta$-triggered AP-1 and NF-kB activities by rapamycin.}

(A, upper panel). Western blot analysis demonstrating a dose-dependent amplification of the IL-1 $\beta$-induced content of nuclear phospho-c-Jun and nuclear translocation of the NF- $\mathrm{B}$ subunit p65 by rapamycin. Serum-starved MC were stimulated for 30 min with either vehicle (-), IL-1 $\beta(2 \mathrm{nM})$, rapamycin $(100 \mathrm{ng} / \mathrm{ml})$, or a combination as indicated before cells were harvested for nuclear extracts. For Western blot analysis $50 \mu \mathrm{g}$ of nuclear extracts (nuclear) were subjected to Western blot analysis and successively probed with an anti-phospho-c-Junspecific (p-c-Jun-Ser63), anti-c-Jun-specific (c-Jun) and anti-p65-specific antibodies, respectively. Loading of equal amounts of nuclear extract was ascertained by reprobing the blots with an anti-HDAC-1 antibody. (A, lower panel). Protein lysates (60 $\mu \mathrm{g})$ from corresponding cytoplasmic fractions were subjected to SDS-PAGE and immunoblotted using an anti-IкB $\alpha$ polyclonal antiserum. To correct for variations in the protein loading, the blot was stripped and reincubated with an anti- $\beta$-actin antibody.(B). The DNA-binding of NF- $\kappa \mathrm{B}$ (upper panel) and AP-1 (lower panel) was analysed by EMSA using gene-specific oligonucleotides from the rat MMP-9 promoter as described in 2.8. $5 \mu \mathrm{g}$ of the same nuclear extract preparations described in (A) were incubated in the binding reaction and DNA-bound 
complexes were resolved from unbound DNA by non-denaturating gel electrophoresis. The EMSAs shown are representative of three independent experiments giving similar results. Supershift analysis shown on the right panels identifying p65 as a major constituent of NF- $\mathrm{kB}$ (upper panel) and c-Jun as a main constituent of the AP-1-bound complex (lower panel). For supershift analysis, the indicated antibodies were applied as described in "Materials and Methods."

Figure 4. Rapamycin amplifies IL-1 $\beta$-induced MMP-9 promoter activity via a proximal AP-1 binding site at $\mathbf{- 8 7}$.

(A). Schematic representation of the different $1.3 \mathrm{~kb}$ MMP-9 luciferase constructs, either nonmutated (pGL3-MMP-9) or modified by single point mutations of the indicated transcription factor binding sites. $(B, C)$. Promoter activities of wild-type (pGL3-MMP-9) (B, left panel) or corresponding pGL3-MMP-9 promoter contructs point mutated in a NF-kB

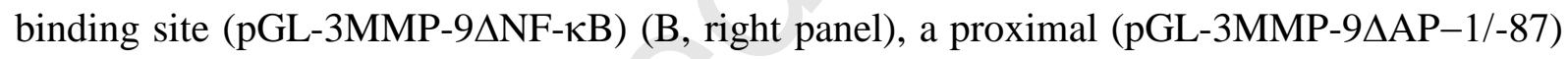
(C, left panel) or a distal AP-1 binding site (pGL-3MMP-9 $\Delta$ AP-1/-504) (C, right panel). After overnight transfection, MC were left untreated (vehicle), or treated for 24 hours with IL$1 \beta(2 \mathrm{nM})$, rapamycin $(100 \mathrm{ng} / \mathrm{ml})$, or both in combination as indicated. Preparation of cells and subsequent measurement of dual luciferase activities was done as described in 2.5. The values for beetle luciferase were related to values for Renilla luciferase and are depicted as relative light units (RLU). Data represent means $\pm \mathrm{SD}(n=6)$. $\mathrm{P} \leq 0.01$ (**,\#\#) or $\mathrm{p} \leq 0.005$ $(* * *)$ compared with control $(* *)$ or with IL-1 $\beta$-stimulated values $\left({ }^{\# \#}\right)$.

Figure 5. Inhibitory impact of the 3'-UTR of MMP-9 on rapamycin-triggered MMP-9 promoter induction. (A). Quiescent MC were left untreated (vehicle) or stimulated for $20 \mathrm{~h}$ with IL-1 $\beta(2 \mathrm{nM})$ to reach a maximal level of MMP-9 mRNA. Thereafter, cells were washed 
and incubated with actinomycin D (Act D, $5 \mu \mathrm{g} / \mathrm{ml}$ ) before being either directly extracted for total cellular RNA (vehicle, IL-1 $\beta$ ), or additionally treated for further $12 \mathrm{~h}$ in the presence (IL$1 \beta+$ ActD+Rapa) or absence (IL-1 $\beta+$ Act D) of rapamycin $(100 \mathrm{ng} / \mathrm{ml})$. Changes in MMP-9 mRNA levels were determined by qRT-PCR by normalising MMP-9 mRNA to either EEF-2 mRNA (white bars), or to GAPDH mRNA (black bars). The results are means $\pm \operatorname{SD}(n=4)$ and are presented as relative MMP-9 mRNA values. (B). The schematic drawing depicts a luciferase construct of a $1.3 \mathrm{~kb}$ fragment of the rat MMP-9 wild-type promoter which additionally contains the $3^{\prime}$-UTR of rat MMP-9 downstream of the luciferase coding region (pGL-3-MMP-9/3'-UTR). This construct was used for assessment of a modulatory impact of the 3'-UTR on MMP-9 promoter activity. Luciferase activities of pGL3-MMP-9/3'-UTR are shown at the bottom. After overnight transfection, MC were left untreated (vehicle), or treated for 24 hours with IL-1 $\beta(2 \mathrm{nM})$, rapamycin $(100 \mathrm{ng} / \mathrm{ml})$, or both in combination as indicated. The values for beetle luciferase were related to values for Renilla. Data represent means \pm SD $(n=6) . \mathrm{P} \leq 0.005(* * *)$ compared with control. 
Figure 1

A.
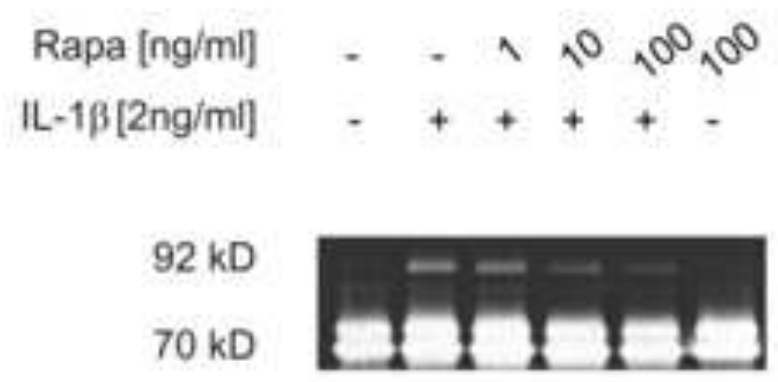

B.

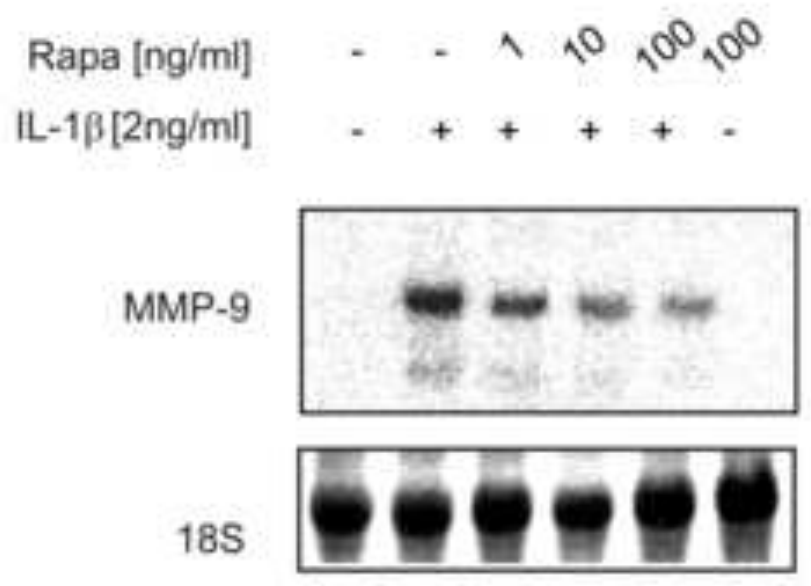



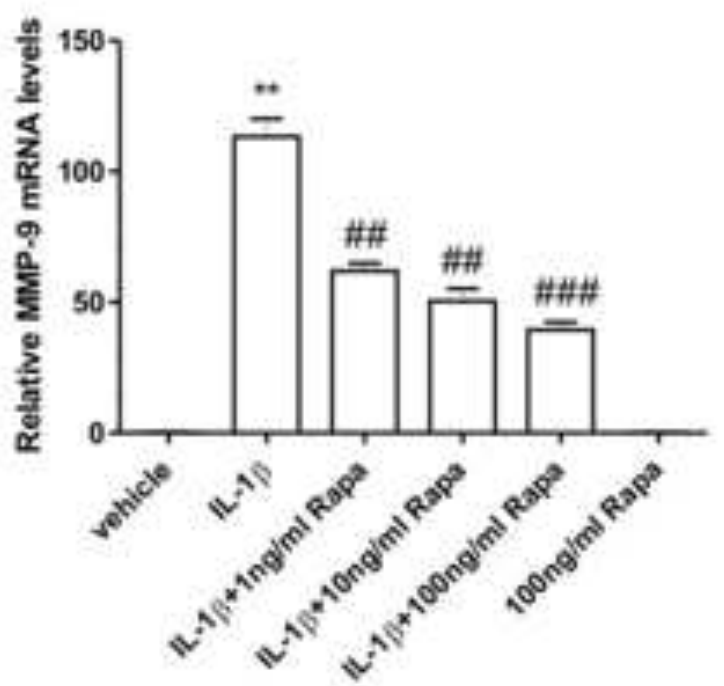

Page 31 of 38 


\section{Figure 2}

A.

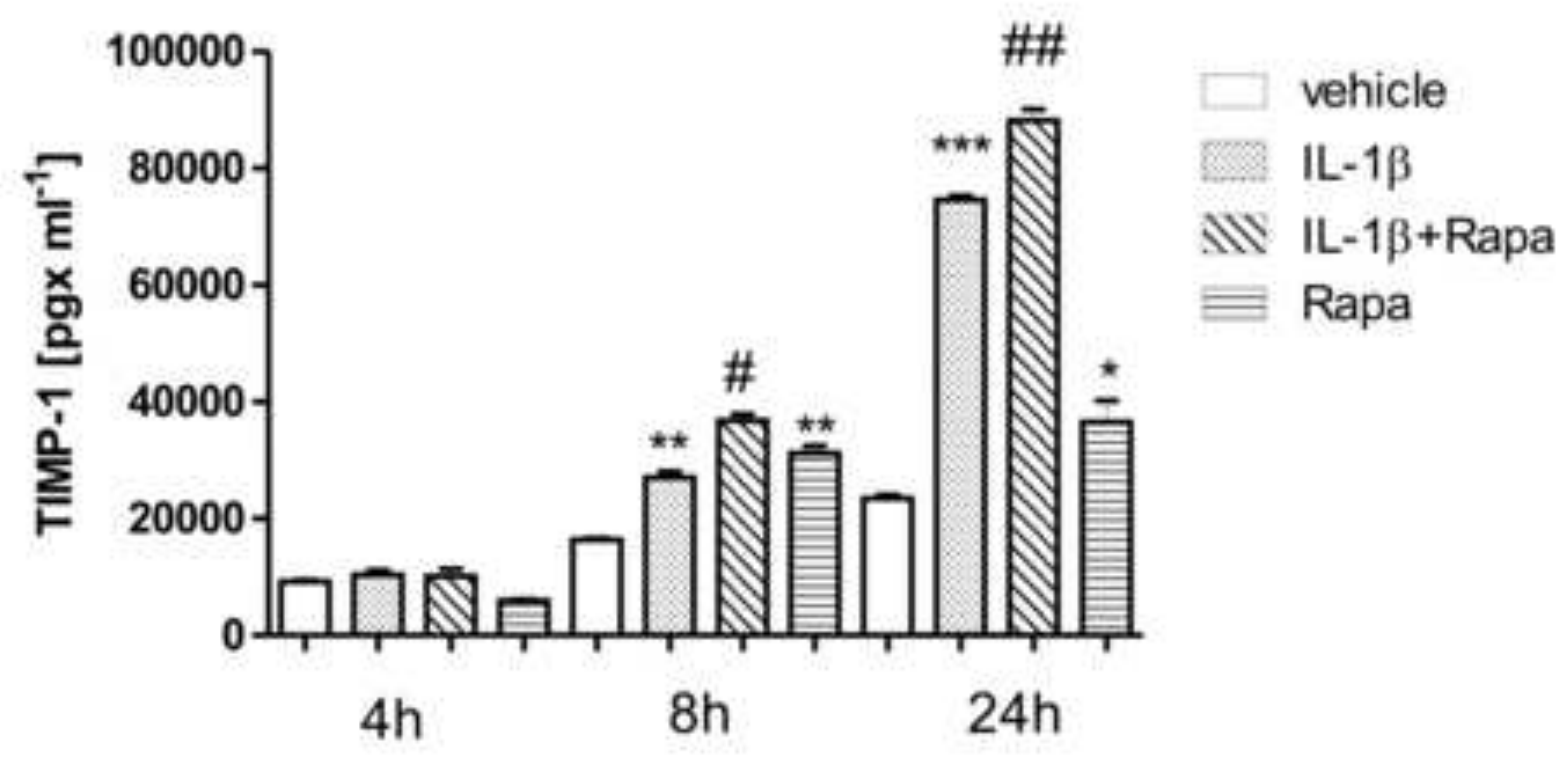

B.
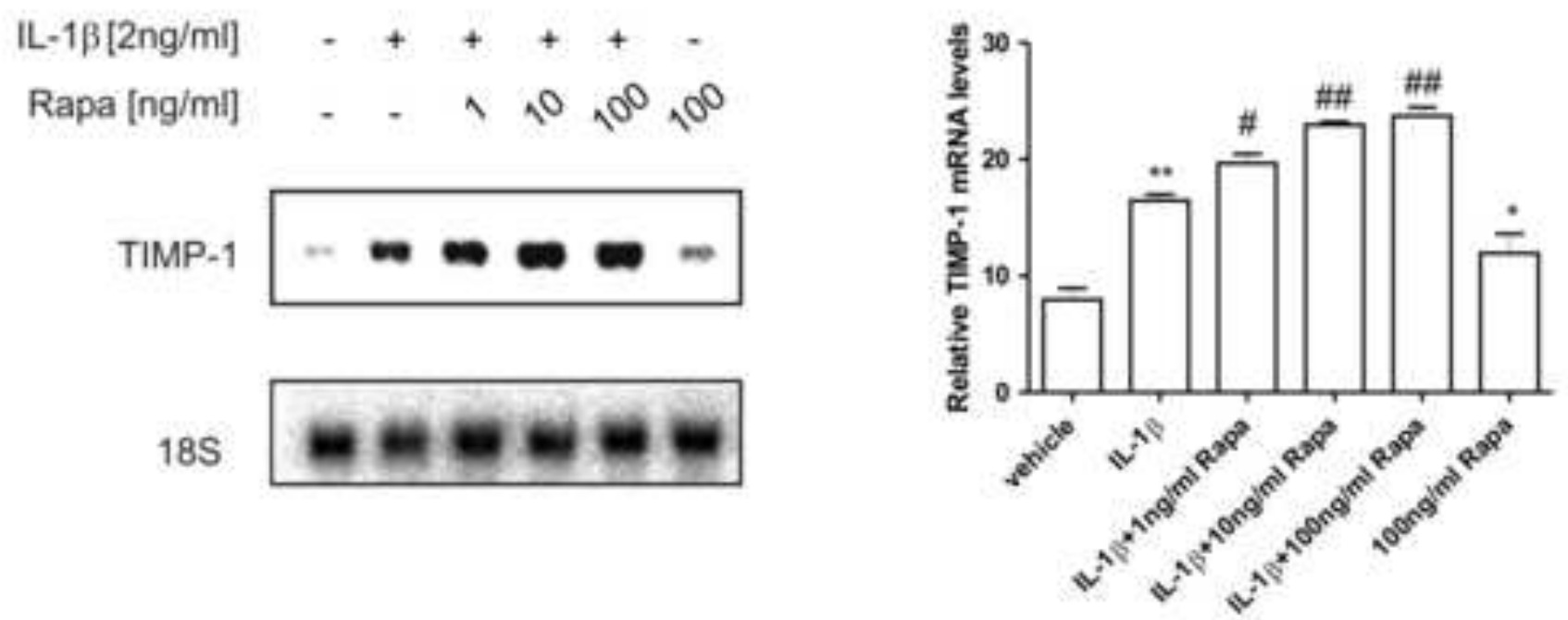
Figure 2

C.
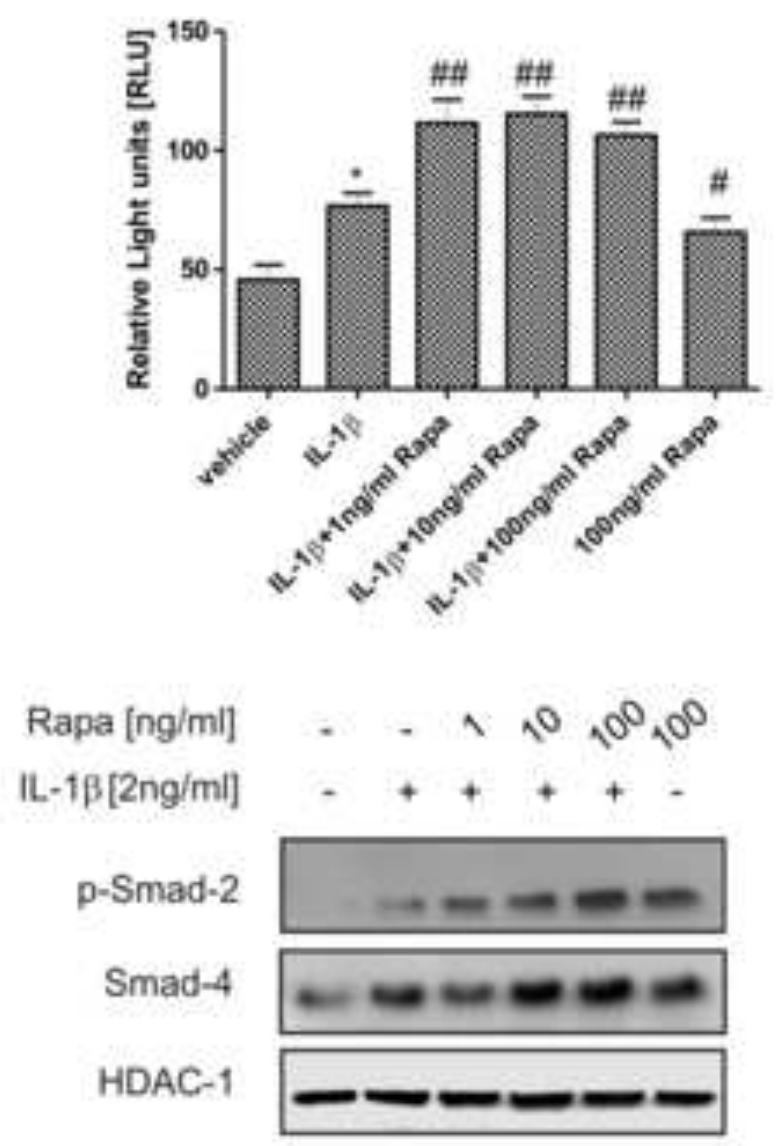

D.

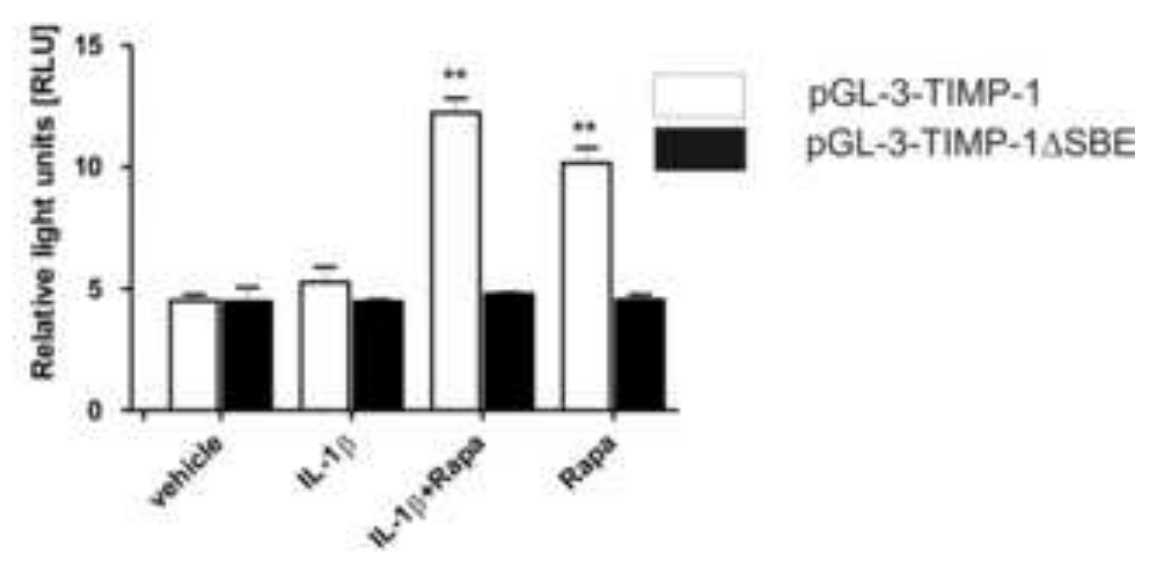


Figure 3

A.

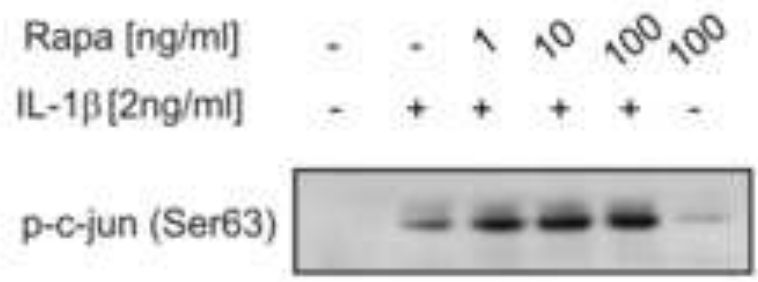

nuclear:

c-jun

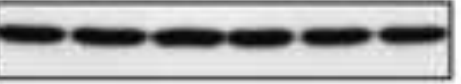

p65

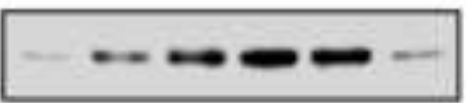

HDAC-1
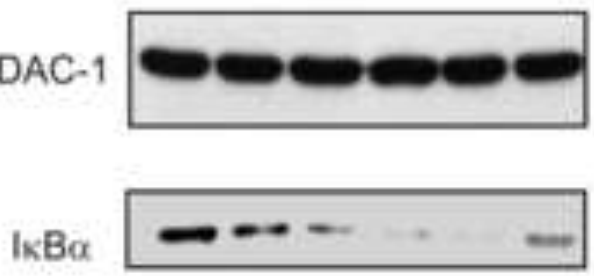

cytoplasmic:

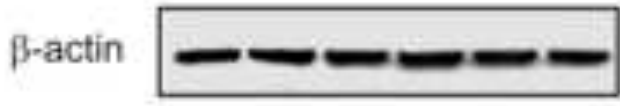

B.
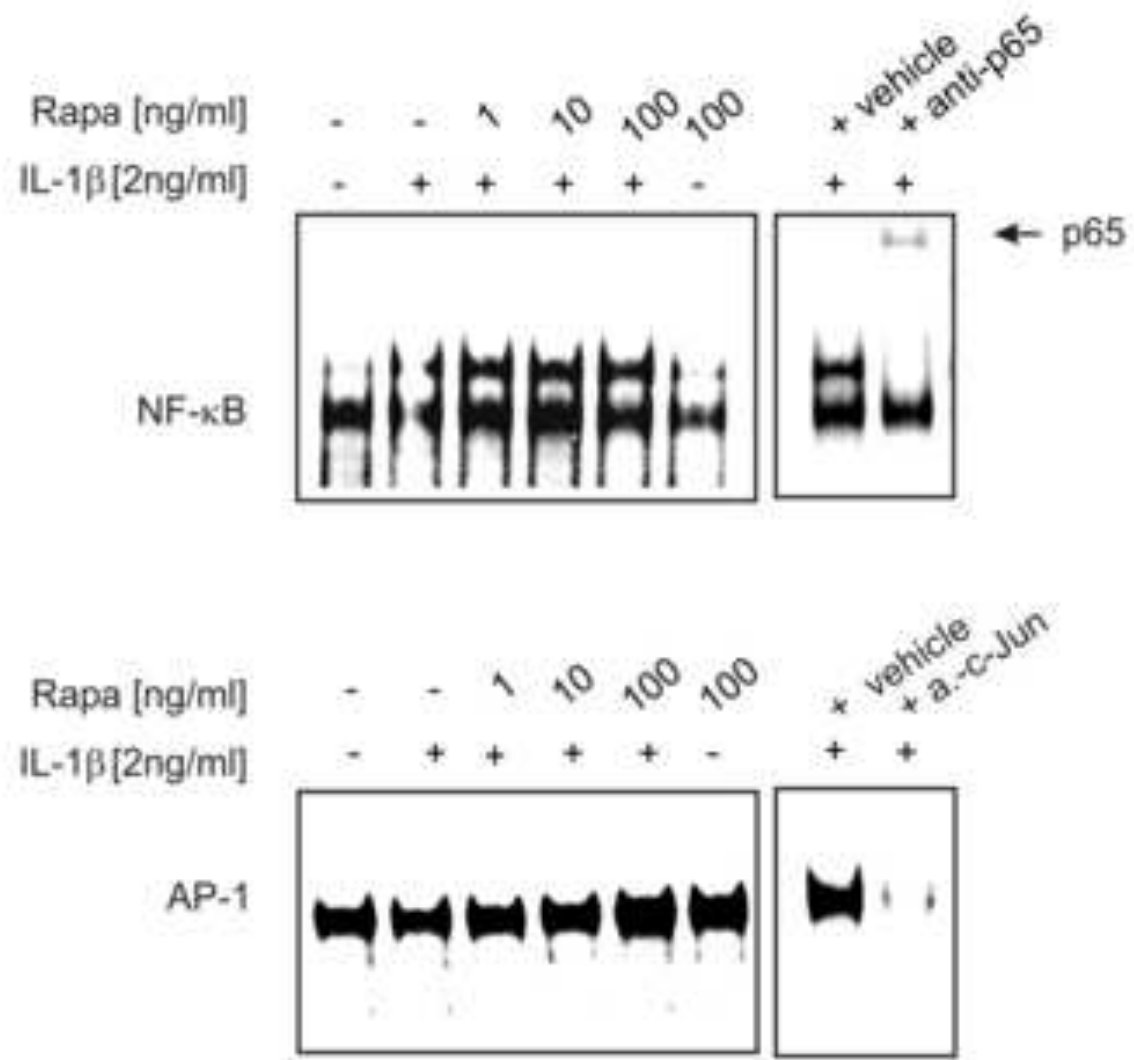
Figure 4

A.

pGL3-MMP-9 $\triangle N F-\kappa B$

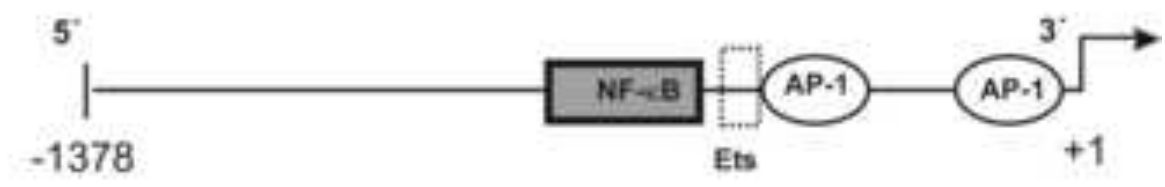

PGL3-MMP-9 $\triangle A P-1 /-87$

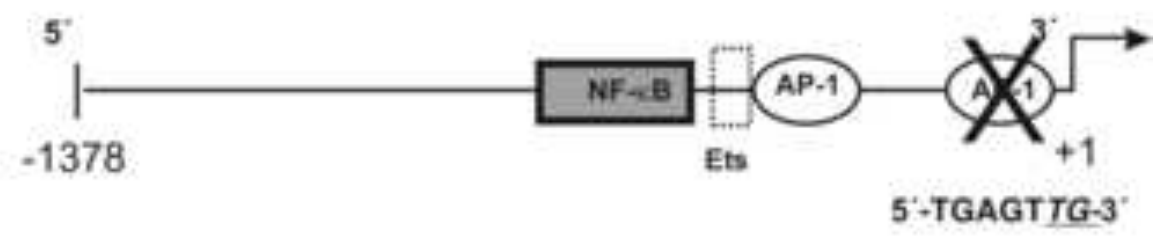

PGL3-MMP-9 $\triangle A P-1 /-504$

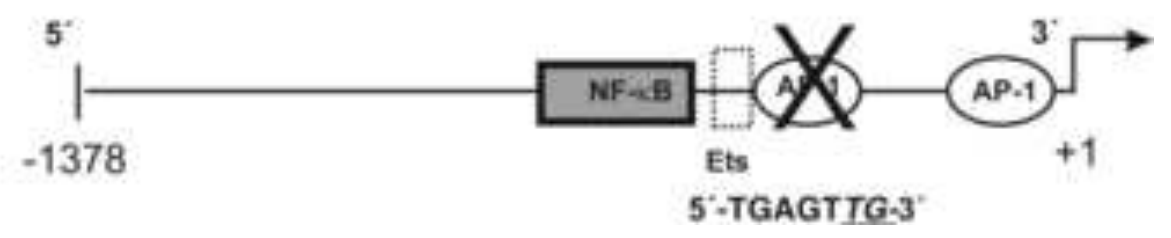


Figure 4

B.
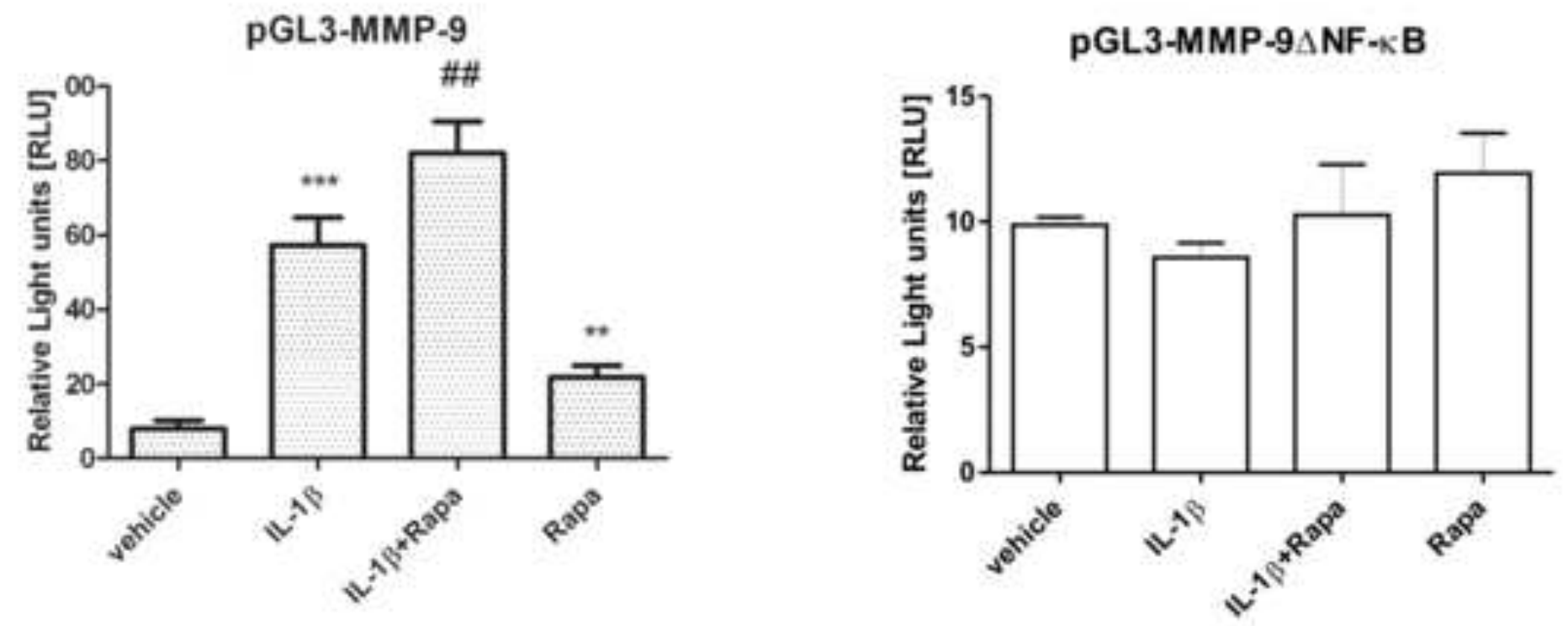

C.

pGL3-MMP-9 $\triangle A P-1 /-87$
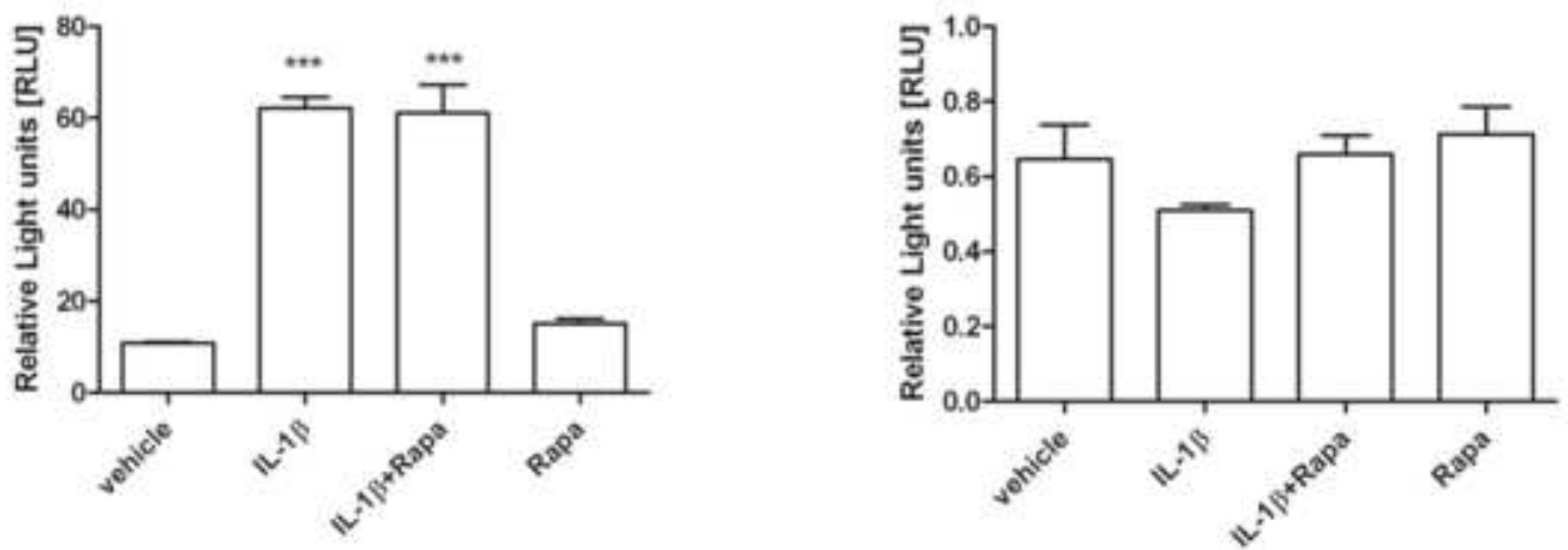
Figure 5

A.

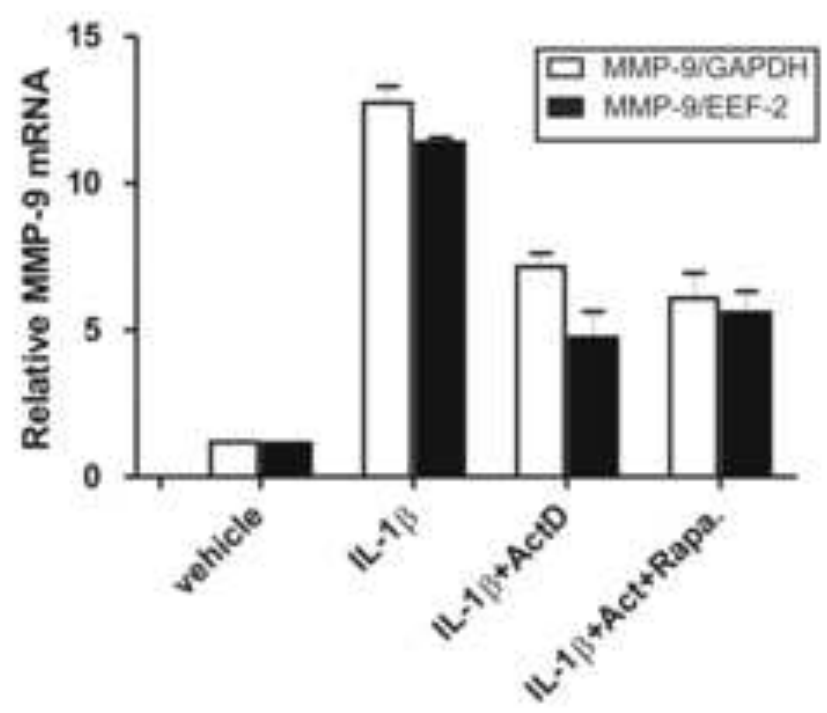

B.

PGL3-MMP-9/3'-UTR
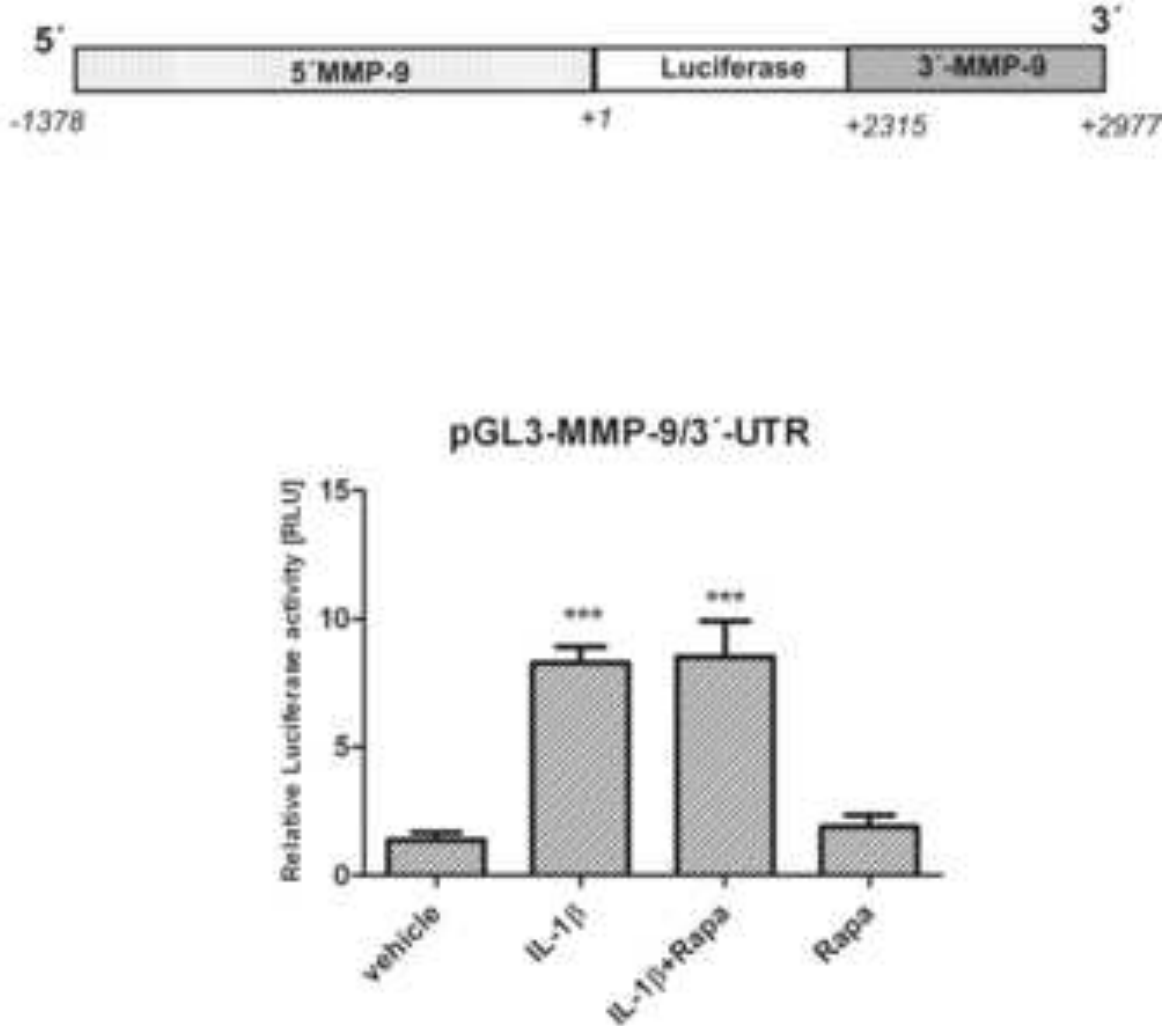

Page 37 of 38 


\section{Rapamycin}
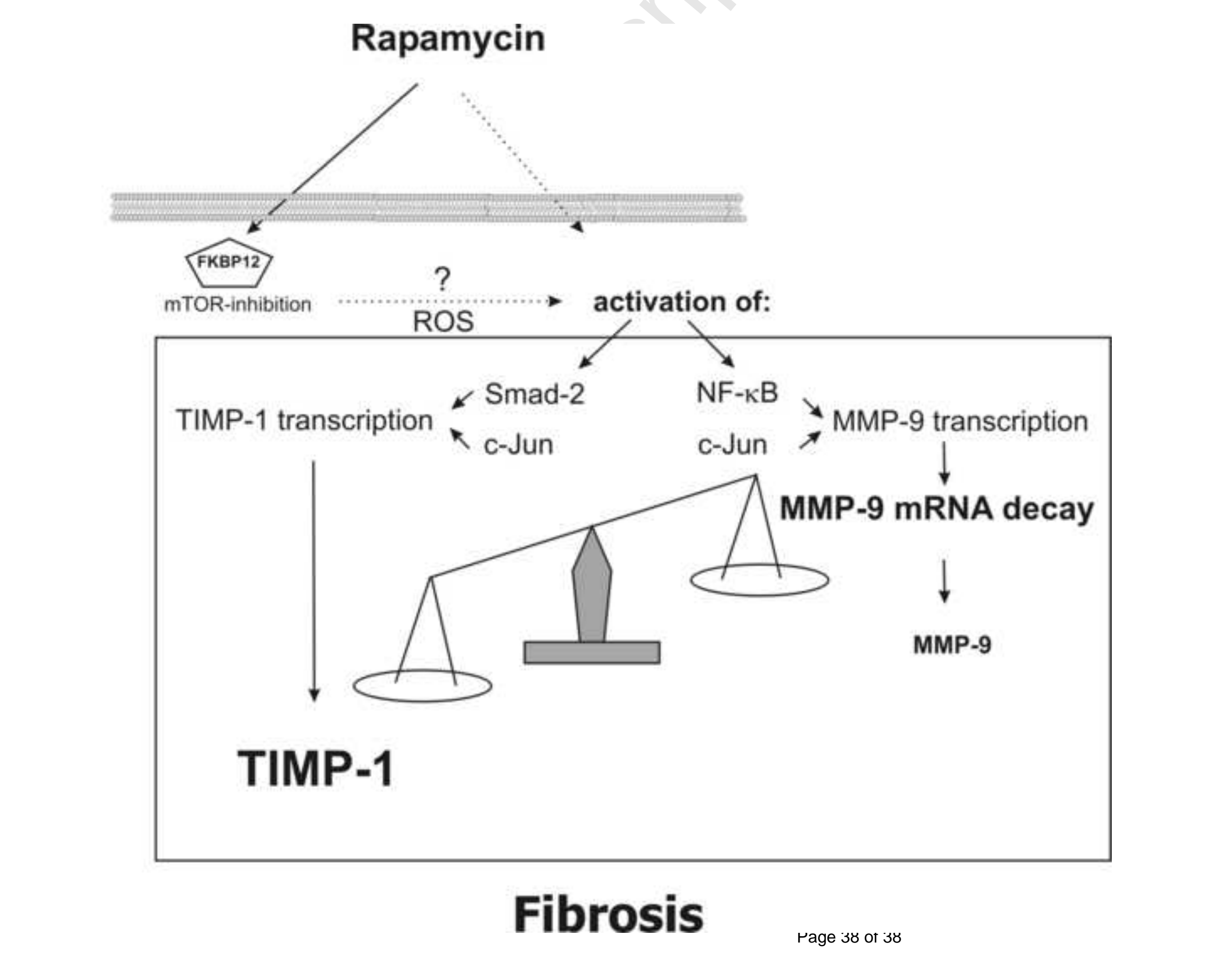

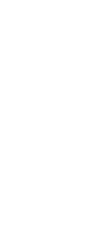

